\title{
THE ROLE OF RAILWAYS IN EXPORT-LED GROWTH: THE CASE OF URUGUAY, 1870-1913
}

\author{
Alfonso Herranz-Loncán \\ University of Barcelona
}

\begin{abstract}
The social saving literature has highlighted the indispensable role that railways played before 1914 in several Latin American export-oriented economies, such as Mexico, Brazil or Argentina. This paper analyses the case of Uruguay, a country that, by 1914, had built one of the densest railway networks in Latin America. The paper shows that, in contrast to what happened in other economies of the region, the resource saving effects of the Uruguayan railways during the first globalisation were tiny, due to the small share that railway output accounted for within GDP. Three complementary reasons are suggested to explain that result: the geographical structure of the country, its sectoral specialisation and the small scale of the Uruguayan economy. Due to these three characteristics, Uruguay was unable to benefit from railways in the way that other export-oriented Latin American economies did during the first period of globalisation. This conclusion draws attention to the geographic-specific character of railway technology.
\end{abstract}

JEL code: N76

Keywords: Railways, Uruguay, Export-led Growth 


\section{THE ROLE OF RAILWAYS IN EXPORT-LED GROWTH: THE CASE OF URUGUAY, 1870-1913 ${ }^{1}$}

\section{Introduction}

The railways were an essential component of the transport revolution that made the first globalisation possible and had a huge growth impact in several Latin American export-oriented economies. In countries such as Argentina, Brazil or Mexico, the railways created and strengthened the links between previously fragmented local markets, and also between them and the world markets, having a much more developmental character in those countries than in the core economies, which already had relatively efficient and competitive market structures at the beginning of the railway era (Coatsworth, 1981; Summerhill, 2000 and 2003; Kuntz Ficker, 1999; Dobado and Marrero, 2005). Actually, in Summerhill's words, “(...) it now seems unlikely that any other technological or institutional innovation was more important in the transition to economic growth in Latin America before 1930" (Summerhill, 2006: 297).

Uruguay, like other Latin American economies that participated actively in the first globalisation era, also undertook an intense process of railway construction during the last few decades of the nineteenth century, and its railway network was one of the densest in the continent by 1913. However, assessments of the role that railways played on the transformation of the Uruguayan economy during the first globalisation boom have been rather pessimistic. Both contemporaries and subsequent historians have insisted that the Uruguayan railways were badly constructed and managed, did not respond to the country's needs, and had no impact on either the diversification of production or the increase in the available stock of natural resources due, among other reasons, to the business strategy of the railway firms (see, e.g. García Acevedo, 1892, p. 47; Vázquez, 1931; Nahum and Barrán, 1971, p. 535-613; Millot and Bertino, 1996, p. 345; Winn, 2010, p. 251).

\footnotetext{
${ }^{1}$ I thank Jorge Álvarez, Magadalena Bertino, Luis Bértola, Reto Bertoni, Enrique Bianchi, María Camou, Werther Halarewicz, Raul Jacob, Javier Rodríguez-Weber, Carolina Román, Henry Willebald and the participants at seminars at the University of the Republic (Uruguay) and the University of Barcelona for their very useful comments and help with data sources. This paper has benefited from the financial support of projects ECO2009-13331-C02-02/ECON and PR2009-0505 (Spanish Ministry of Science and Innovation).
} 
In this context, this paper aims at providing a global estimation of the direct impact of Uruguayan railways on economic growth before 1914 and providing some possible explanations for the low level of that impact and the apparent exceptionality of the Uruguayan economy in the Latin American context. To that purpose, the next section provides a short survey of the characteristics of the Uruguayan railway system during the first globalisation period; Section 3 presents an estimation of the social savings of the Uruguayan railway system by 1912-13; Section 4 analyses some of the potential explanatory factors of the social saving estimation outcomes; and Section 5 concludes.

\section{The Uruguayan railway system (1869-1914)}

Railway construction in Uruguay started relatively late, compared with other leading Latin American economies such as Cuba (whose first railway line was opened in 1837) or Argentina, Brazil, Colombia, Chile, Mexico and Peru (where construction started in the 1850s). Due mostly to the enduring economic devastation provoked in the country by the Guerra Grande, ${ }^{2}$ there were no serious initiatives for railway construction until the mid 1860s, and the first railway stretch, of just $20 \mathrm{~km}$, was only opened in 1869. However, despite that delay, by the eve of World War One Uruguay had built a railway system of $2,577 \mathrm{~km}$, which was among the densest in the continent, both in per capita terms and relative to the country's surface area. Compared with European networks, the per capita mileage of the Uruguayan railway system was more than twice the European average, although it ranked much lower in relation to the country's area, due to the large difference in population density between Uruguay and Europe.

\footnotetext{
${ }^{2}$ The Uruguayan Civil War, also known as "Guerra Grande" (Great War), was a series of armed conflicts that took place between the two factions that disputed power in 19th century Uruguay (the "Colorado" and the National Parties) from 1839 to 1851.
} 
Table 1. Railway network mileage in 1912.

\begin{tabular}{|c|c|c|c|}
\hline & $\begin{array}{l}\text { Mileage/population } \\
\text { (Railway km per } \\
\text { 10,000 pop.) }\end{array}$ & & $\begin{array}{l}\text { Mileage/surface area } \\
\text { (Railway } \mathrm{km}_{\mathrm{per}} \\
\left.\text { 1,000 } \mathrm{km}^{2}\right)\end{array}$ \\
\hline Argentina & 42.65 & Puerto Rico & 38.88 \\
\hline Uruguay & 21.78 & Cuba & 33.37 \\
\hline Chile & 21.20 & Salvador & 15.44 \\
\hline Costa Rica & 16.51 & Uruguay & 13.52 \\
\hline Cuba & 16.13 & Costa Rica & 11.95 \\
\hline Mexico & 14.22 & Argentina & 11.39 \\
\hline Brazil & 9.53 & Mexico & 10.37 \\
\hline Peru & 7.46 & Chile & 9.87 \\
\hline Guatemala & 7.08 & Guatemala & 7.43 \\
\hline Bolivia & 6.03 & Dominican Republic & 4.90 \\
\hline Paraguay & 5.83 & Haiti & 3.62 \\
\hline Nicaragua & 5.67 & Brazil & 2.76 \\
\hline Ecuador & 3.81 & Nicaragua & 2.49 \\
\hline Venezuela & 3.31 & Paraguay & 2.32 \\
\hline Dominican Republic & 3.14 & Peru & 2.31 \\
\hline El Salvador & 3.13 & Ecuador & 2.06 \\
\hline Puerto Rico & 3.05 & Honduras & 1.53 \\
\hline Honduras & 2.96 & Colombia & 1.03 \\
\hline Colombia & 2.09 & Panama & 1.01 \\
\hline Panama & 1.78 & Bolivia & 0.99 \\
\hline Haiti & 0.58 & Venezuela & 0.94 \\
\hline $\begin{array}{l}\text { Latin America } \\
\text { (weighted average) }\end{array}$ & 12.94 & $\begin{array}{l}\text { Latin America } \\
\text { (weighted average) }\end{array}$ & 5.01 \\
\hline$U S$ & 26.65 & $U S$ & 25.69 \\
\hline $\begin{array}{l}\text { Europe (weighted } \\
\text { average) }^{\mathrm{a}}\end{array}$ & 10.07 & $\begin{array}{l}\text { Europe (weighted } \\
\text { average) }\end{array}$ & 61.53 \\
\hline
\end{tabular}

Sources: Own elaboration from Mitchell (2003a) and (2003b), Maddison (2001), and Banks' CNTS Archive.

Note: (a) In 1910; Russia excluded.

As in other countries, the construction of Uruguayan railways was highly concentrated in a few years; 44 percent of the mileage in operation in 1913 was opened between 1885 and 1891. The structure of the railway network was extremely centralised, mainly consisting of a series of lines that connected the extreme points of the country with Montevideo (see Map 1). ${ }^{3}$ Unlike other neighbouring countries, which had a significant share of State railways, the whole network was privately owned by a few British companies. By 1913, 61 percent of the network mileage was operated by the Central Uruguay Railway Company, and 20 percent was in the hands of the Midland Uruguay Railway. The remaining 19 percent of the mileage was distributed among five very small companies, which operated networks ranging from 20 to $181 \mathrm{~km}$.

\footnotetext{
${ }^{3}$ According to Millot and Bertino (1996), p. 352, this structure reproduced the pre-existing trade flows. An exception to centralisation was the "North Western of Uruguay Railway Company", which connected Salto and Santa Rosa and was initially aimed at carrying Brazilian and Uruguayan products to the port of Salto, over the Uruguay River, to be shipped from there to their destination by water. However, this line was also finally connected with Montevideo through the Midland Uruguay Railway.
} 
Map 1. The Uruguayan railway network by 1914

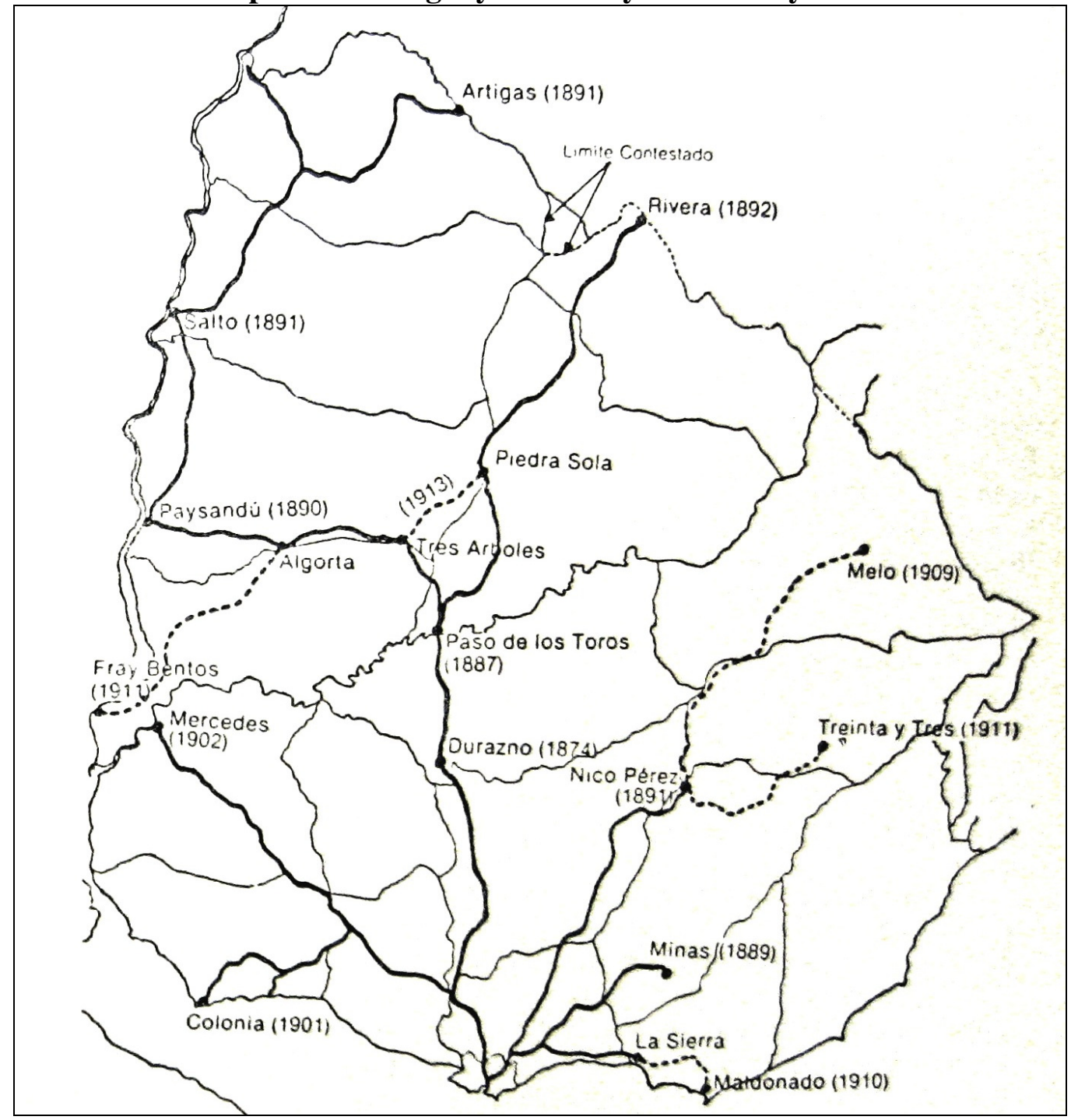

Note: The thick solid lines indicate the railways constructed before 1904, and the broken lines show the railways constructed between 1904 and 1914.

Source: Barrán and Nahum (1978), p. 129.

The construction of the railway system accompanied the development of the modern Uruguayan economy. When the first railway line was opened, Uruguay was a small society with a population of ca. 400,000 , of which almost one third lived in Montevideo, and which had no significant transport infrastructure (see Baracchini, 1978: 130-45). The country was deeply transformed in the next few decades and, by the eve of World War One, the Uruguayan population had trebled, and exports and GDP were 4 and 5 times as large as in 1870, respectively. Figure 1 shows that the construction of the railway network ran parallel to that economic transformation, being 
the main infrastructure investment and one of the main destinations of foreign capital during the period. ${ }^{4}$

Figure 1. Railway mileage, GDP and exports in Uruguay (1870-1913) $(1913=100)$

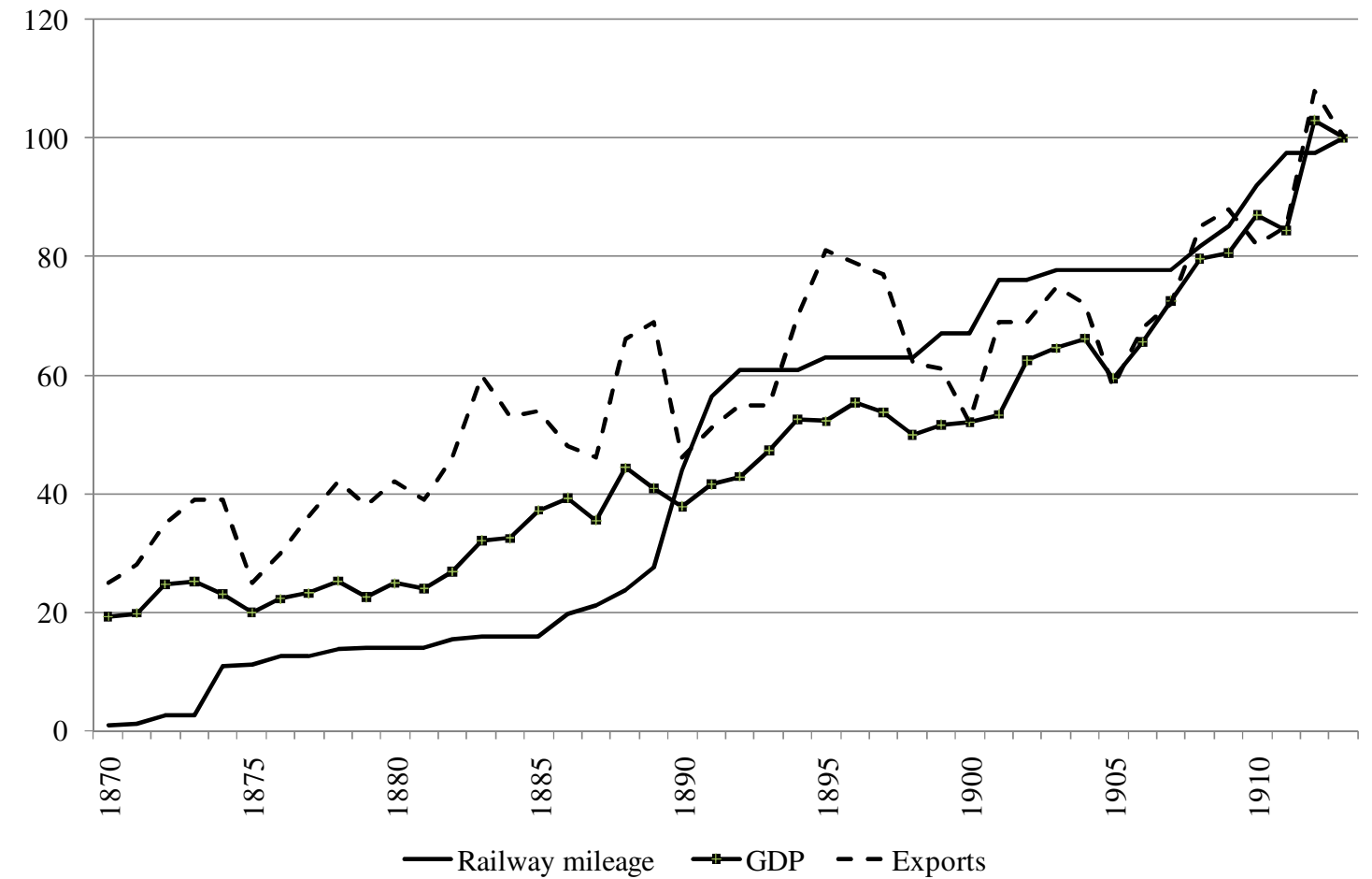

Sources: railway mileage, own elaboration from the country's statistical yearbooks; GDP from Bértola (1998), and exports from Bértola (2000), pp. 84-85.

Railway transport represented a growing share of Uruguayan GDP throughout the period under analysis, reaching a level of 2 to 2.5 percent of the country's total output in the decade before World War One (see Figure 2). However, the ratio between railway revenues and GDP was much higher in Argentina, Brazil or Mexico by the same dates (between 3.5 and 6 approximately; see Herranz-Loncán, 2011). This may be taken as a first indication that the railways did not perform the same function in Uruguay as in those countries during the export-led growth episode of 1870-1913. The next section tests this hypothesis through the estimation of the direct economic benefits that the Uruguayan economy obtained from the railway system before 1914.

\footnotetext{
${ }^{4}$ Railways accounted for 32 percent of foreign investment in Uruguay during the period under study; see Rodríguez Carrasco (1998), p. 136. A Granger-causality analysis of the series included in Figure 1 shows a close Granger-causal relationship between the development of railway mileage and the growth of exports between 1870 and 1913, in both directions, which is consistent with the foreign origin of railway investment and the use of the railways by a large share of Uruguayan exports. By contrast, the Grangercausality relationship between railway mileage and GDP is not significant.
} 
Figure 2. Railway output/GDP in Uruguay (\%)

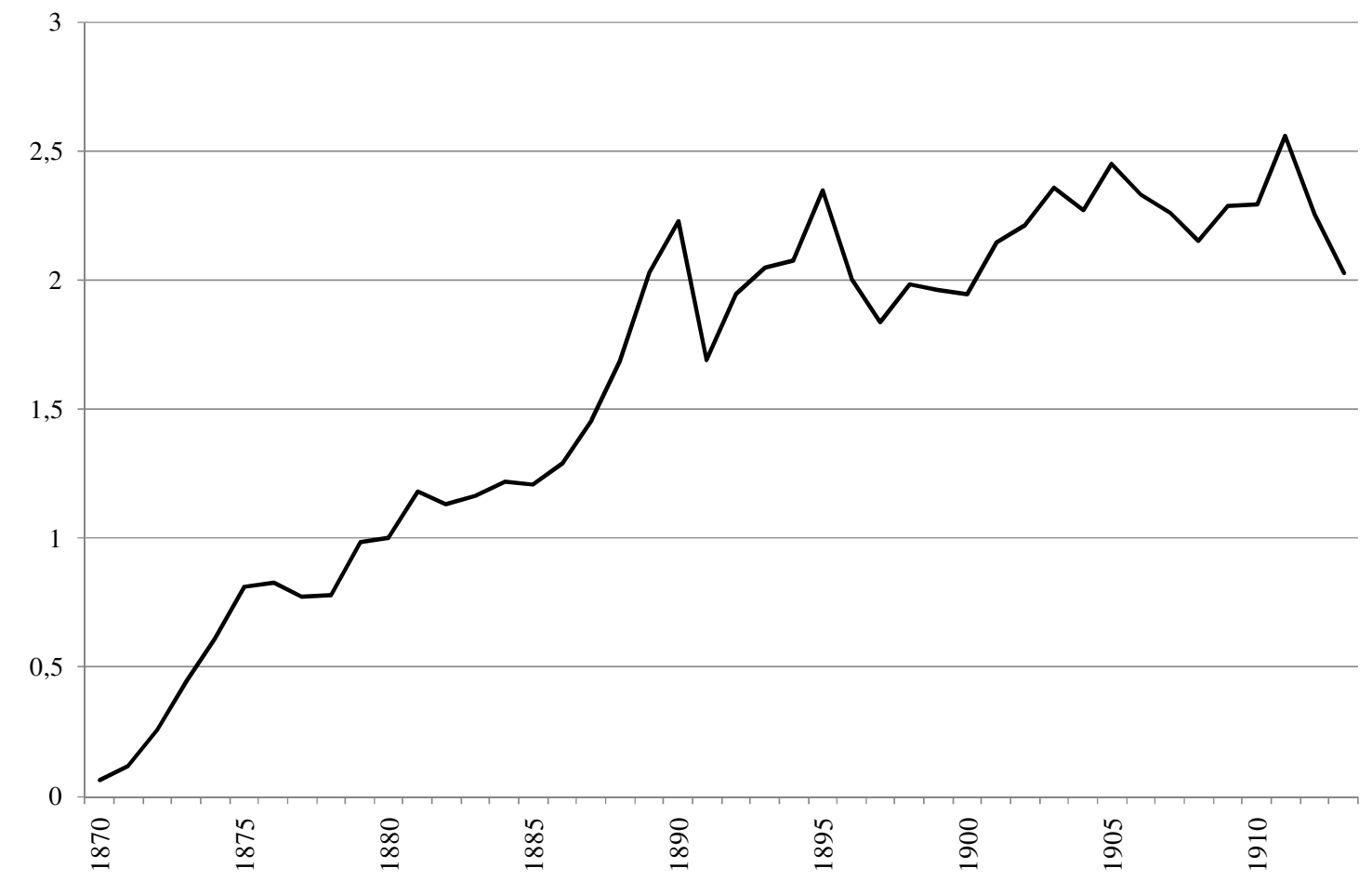

Sources: i) for railway output, Uruguayan Statistical Yearbooks (1884-1915) and Yearly Reports of the Central Uruguay Railway Company, the Midland Uruguay Railway Company, the North Western of Uruguay Railway Company and the Sociedad del Ferrocarril y Tranvía del Norte; ii) nominal GDP is calculated on the basis of its level in 1955 and its previous evolution, as estimated by Bertino and Tajam (1999) and Bértola (1998).

Note: i) Gaps of revenue information for some of the smallest companies in some years (e.g. North Western in 1874-82 and 1904-08, Uruguayo del Este in 1892-1908, Uruguay Northern in 1904-07 or Ferrocarril y Tranvía del Norte before 1889) are filled by assuming a similar ratio of revenues per $\mathrm{km}$ between those companies and the Central Uruguay Railway as in the closest years for which complete data are available. ii) In the case of the railway of Puerto del Sauce (42 km), which was opened to traffic in 1903, no revenue or expenditure data are available. Therefore, in order to account for its traffic, I have increased the total revenues of the system by the percentage that this line represented in the whole network mileage (around 1.9 percent on average).

\section{The social saving of the Uruguayan railways by 1912-13}

The estimation of social savings constitutes a preliminary way to approach the direct economic benefits that the economy obtained from the railways. The social savings are intended to measure the resources released by the railway technology in transport activities. This is achieved by calculating the cost of transporting the railway freight and passengers of one year by the best available alternative. Social savings are therefore the result of estimating the following expression:

$$
S S=\left(P_{A L T}-P_{R W}\right) x Q_{R W}
$$

where $P_{R W}$ and $P_{A L T}$ are, respectively, the price of railway and counterfactual (alternative) transport, and $Q_{R W}$ is the freight and passengers transported by the railways in the reference year. This is usually expressed in relative terms, as a percentage of 
GDP. If this expression is corrected to account for the price-elasticity of transport demand, the result would be the equivalent variation consumer surplus provided by the railways which, if perfect competition in the rest of the economy is assumed, provides a general equilibrium measure of the entire direct real income gain obtained from reducing resource costs in transportation (Metzer, 1984).

The level of this gain depends therefore on three magnitudes: the relative size of the railway sector $\left(Q_{R W} / G D P\right)$, the unit savings in transport cost provided by the railways $\left(P_{A L T}-P_{R W}\right)$ and the price elasticity of transport demand in each country. In the next paragraphs, I provide estimates of these three magnitudes and the direct income gain resulting from them for both freight and passenger transport in Uruguay in 1912$13 .^{5}$

\subsection{Freight social savings}

In 1912-13 the Uruguayan railway system transported 305.8 million ton-km, and charged an average fee of 0.016 pesos per ton- $\mathrm{km} .{ }^{6}$ In the absence of the railways, that freight would have been moved through a combination of river navigation and road transport. Opposite to the situation in other Latin American countries, like Mexico or Brazil, the geography of Uruguay offered a huge potential for water transport use, since a large part of the contour of the country is surrounded by the river Uruguay and the La Plata estuary, where water transport was highly developed before the arrival of the railways, and some railway lines, such as the Ferrocarril Uruguayo del Este (Montevideo-Maldonado), the Colonia branch of the Central Uruguay Railways or the route between Paysandú and Salto, ran parallel and very close to the riverbanks. Nevertheless, river navigation was not a feasible alternative for traffic coming from the North or Northeast of the country, or from areas bordering the Uruguay River upstream from Salto, due to the presence of waterfalls. In the absence of the railways, that traffic would have been transported by road, which was much more expensive than railways or navigation.

\footnotetext{
${ }^{5}$ As in similar research for other countries I exclude from the analysis some sorts of traffic, like highspeed freight or excess luggage which, according to the 1913-14 Uruguayan Statistical Yearbook, accounted for ca. 5 percent of the total revenues of the Uruguayan railways in 1912-13.

${ }^{6}$ Figures estimated from information in the country's Statistical Yearbook. There are no data available on the freight transported by the Sociedad del Ferrocarril y Tranvía del Norte $(20 \mathrm{~km})$ and the railway of Puerto del Sauce $(42 \mathrm{~km})$. For the former, I estimate freight to be 1.8 percent of the freight of all other companies, on the basis of revenue data, and under the assumption that this railway charged the average rate of the system. For the latter, given the lack of revenue data, I increase total railway freight by 1.6 percent, which was the share of this company within total railway mileage in 1912-13.
} 
There is some information available on the rates charged by river and road carriers during the period under study. Although, as is usual in this kind of exercise, this information could hardly pass the standard tests applied to representative samples of data (O'Brien, 1977: 113), it allows calculating preliminary estimates of the unit cost savings provided by the railway technology. For river navigation, Mourat (1973: 88) reports that the average price of freight transport by river between Montevideo and Salto or Concordia (both at a similar distance from Montevideo on either side of the Uruguay river) was 2.5 pesos per ton in 1913, i.e. 0.0040 pesos per ton-km (or 0.0042 pesos if it is considered, in the context of the social saving calculation, that the distance between Montevideo and Salto was 6 percent longer by river than by railway). According to Mourat (1977: 43) those prices had remained quite stable in nominal terms at least since 1899. In addition, Nahum and Barrán (1971: 626-27) indicate that the transport of $100 \mathrm{~kg}$ of wheat from Colonia to Montevideo cost 0.2 pesos ca. 1900, i.e. 0.0111 pesos per ton-km. If this figure is corrected for the evolution of prices in the first years of the $20^{\text {th }}$ century and for the fact that the distance between those cities was 37 percent longer via rail than by boat, the resulting counterfactual rate per ton-km would be 0.0116 pesos. ${ }^{7}$ As might be expected, those two alternative rates (0.0042 and 0.0116 pesos per ton-km) were significantly lower than the average railway freight transport fee (0.016), which clearly indicates that the advantages of the railways over water transport cannot be ascribed to price but to other factors such as speed and regularity. These, however, were often insufficient for the railways to attract water traffic, except through the application of differential rates. ${ }^{8}$

Those two rates might be taken as upper and lower bounds for navigation prices in the social saving estimation, and their average is very close to the counterfactual water transport rate suggested by Summerhill for Argentina (the equivalent of 0.0074 Uruguayan pesos for traffic through the Paraná River). The difference between them would reflect the fact that the unit cost of water freight transport decreases with distance, and it was therefore lower on the Montevideo-Salto route $(626 \mathrm{~km})$ than on the Montevideo-Colonia route $(180 \mathrm{~km})$.

\footnotetext{
${ }^{7}$ All price adjustments are based in the evolution of the GDP deflator estimated by Bértola (1998).

${ }^{8}$ For instance, after the connection of the Central Uruguay Railway network with the North Western Company through the Midland, the latter started charging lower rates to traffic coming from the ports of the Uruguay River; see Martínez Montero (1955), pp. 402-403.
} 
In the case of overland transport, the railways provided a substantial cost decrease over both carting transport and livestock droving. Starting with the former, the successive volumes of the Historia rural del Uruguay moderno by Barrán and Nahum report several rates charged by carting carriers in the late $19^{\text {th }}$ and early $20^{\text {th }}$ centuries, which illustrate the cost advantage of the railways. They are summarised in Table 2.

Table 2. Carting prices in Uruguay (1879-1906)

\begin{tabular}{|c|c|c|c|c|c|}
\hline Source & Year & Route & $\begin{array}{c}\text { Freight } \\
\text { transported }\end{array}$ & $\begin{array}{l}\text { Price in } \\
\text { current } \\
\text { pesos }\end{array}$ & $\begin{array}{l}\text { Price per ton- } \\
\mathrm{km} \text { in pesos } \\
\text { of } 1912-13 \\
\end{array}$ \\
\hline $\begin{array}{l}\text { Acevedo, E., Anales } \\
\text { Históricos, t. IV, p. } 50\end{array}$ & 1879 & $\begin{array}{l}\text { Durazno- } \\
\text { Montevideo } \\
(205 \mathrm{~km}) \\
\end{array}$ & $\begin{array}{l}3 \text { tons of first- } \\
\text { class freight }\end{array}$ & 16 & 0.0313 \\
\hline $\begin{array}{l}\text { Acevedo, E., Anales } \\
\text { Históricos, t. IV, p. } 50\end{array}$ & 1879 & $\begin{array}{l}\text { Durazno- } \\
\text { Montevideo } \\
(205 \mathrm{~km})\end{array}$ & $\begin{array}{l}160 \text { arrobas of } \\
\text { second-class } \\
\text { freight }\end{array}$ & 16 & 0.0511 \\
\hline $\begin{array}{l}\text { Acevedo, E., Anales } \\
\text { Históricos, t. IV, p. } 50\end{array}$ & 1879 & $\begin{array}{l}\text { Durazno- } \\
\text { Montevideo } \\
(205 \mathrm{~km}) \\
\end{array}$ & $\begin{array}{l}192 \text { arrobas of } \\
\text { third-class } \\
\text { freight }\end{array}$ & 16 & 0.0426 \\
\hline $\begin{array}{l}\text { Letter of Santa Rosa } \\
\text { businessmen to the } \\
\text { Central Uruguay Railway }\end{array}$ & 1892 & $\begin{array}{l}\text { Santa Rosa- } \\
\text { Montevideo } \\
(54.3 \mathrm{~km})\end{array}$ & $1,760 \mathrm{~kg}$ of grain & 4.28 & 0.0739 \\
\hline $\begin{array}{l}\text { Letter of Santa Rosa } \\
\text { businessmen to the } \\
\text { Central Uruguay Railway }\end{array}$ & 1892 & $\begin{array}{l}\text { Santa Rosa- } \\
\text { Montevideo } \\
(54.3 \mathrm{~km}) \\
\end{array}$ & $\begin{array}{c}1,800 \mathrm{~kg} \text { of } \\
\text { general freight }\end{array}$ & 4.50 & 0.0759 \\
\hline $\begin{array}{l}\text { El Conciliador, } \\
\text { Maldonado }\end{array}$ & 1896 & $\begin{array}{l}\text { Maldonado- } \\
\text { Montevideo } \\
(114 \mathrm{~km})\end{array}$ & One cart & 6.50 & 0.0559 \\
\hline El Siglo & 1906 & $\begin{array}{c}\text { Melo-Nico Pérez } \\
(191 \mathrm{~km})\end{array}$ & $2,000 \mathrm{~kg}$ & 20 & 0.0621 \\
\hline El Siglo & 1913 & $\begin{array}{c}\text { From an } \\
\text { unidentified } \\
\text { colony to Melo } \\
(30 \mathrm{~km})\end{array}$ & $100 \mathrm{~kg}$ & $\begin{array}{c}0.30 \text { to } \\
0.50\end{array}$ & $\begin{array}{c}0.100 \text { to } \\
0.1667\end{array}$ \\
\hline
\end{tabular}

Sources: Barrán and Nahum (1967), p. 292 and 619; (1973), p. 448; and (1978), pp. 159-160. For the 1896 data, I assume that one cart carried 1.75 tons, following Millot and Bertino (1996), p. 319. To obtain the figures in the last column I have used the GDP deflator estimated by Bértola (1998).

A potential problem of these figures is that, with the exception of the observations in the last two rows, all the rest come from documents aimed at criticising the high level of the railway rates compared with carting prices, rather than from objective reports. However, other available evidence suggests that they might be representative of the actual rates. For instance, the 1882 Yearly Report of the Central Uruguay Railway indicated that the transport of a cartload between Yi and Tacuarembó (a route of $240 \mathrm{~km}$ with no railway alternative yet) was charged 4 pounds, i.e. 0.0555 pesos of 1912-13 per ton-km, which lies within the range of the figures in the table. And, in the case of Argentina, Summerhill (2000, p. 10) estimated the unit cost of road transport between Córdoba and Rosario $(346 \mathrm{~km})$ as 0.083 gold pesos per ton-km in the 
early 1860s, whereas Cortés Conde (1979, p. 187) reported a carting price of 0.075 gold pesos per ton-km in 1883. These rates would be equivalent to 0.0774 and 0.0699 Uruguayan pesos, which are also of a similar order of magnitude to the figures in the table.

In addition, as happened in the case of river navigation, differences among the rates reported in Table 2 seem to be directly related to differences among travel distances. Actually, they fit rather well to a log cost function of distance, as may be seen in Figure 3, which also includes the rate provided by the 1882 Yearly Report of the Central Uruguay Railway. If this function is applied to the average distance travelled by freight through the Uruguayan railway network in $1912-1913(162.82 \mathrm{~km}),{ }^{9}$ the resulting rate is 0.0564 pesos per ton-km, i.e. 3.6 times the average railway fare.

Figure 3. Carting transport unit cost in Uruguay

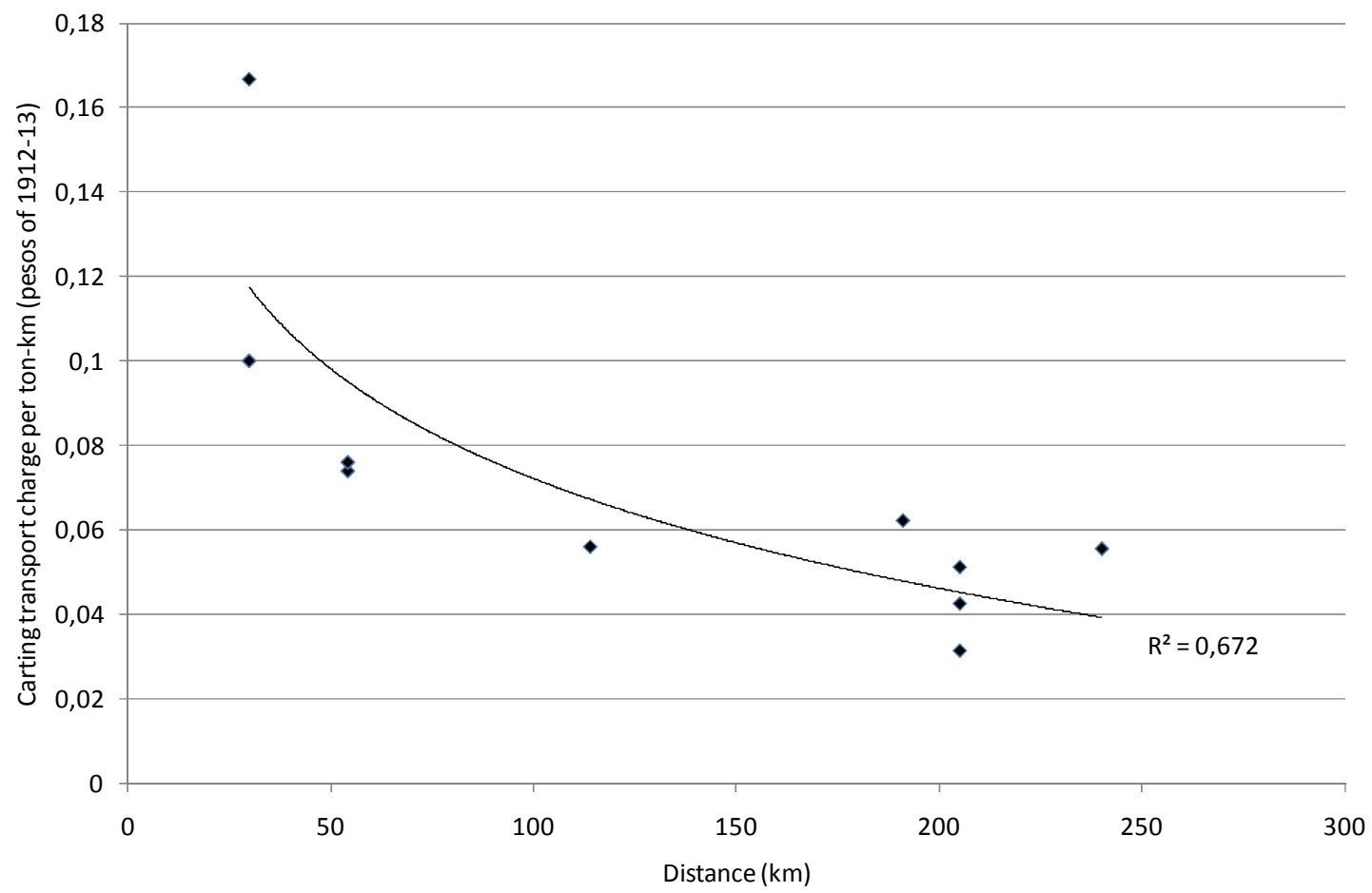

Sources: see text.

As for livestock, here I assume that, in the absence of the railways, it would have been transported by droving. Nahum and Barrán (1971, p. 612) also provide some data on the price of cattle droving per head on several routes (Rivera-Montevideo, Tambores-Montevideo and Río Negro-Casupá) by 1889-92. These prices may be

\footnotetext{
${ }^{9}$ Figure calculated from the 1912-13 Uruguayan Statistical Yearbook (I exclude livestock transport to make the calculation; see below).
} 
transformed into pesos of 1912-13 per ton-km by applying the average weight of cattle slaughtered in Montevideo in $1913(270 \mathrm{~kg}) .{ }^{10}$ The resulting rates range from 0.0093 to 0.0163 , and decrease with distance. This allows one to estimate by means of a log cost function the rate corresponding to the average distance of railway livestock transport in $1912-13(205.8 \mathrm{~km})$. The outcome of this calculation is 0.0140 pesos per ton-km, i.e. a very similar rate to the average railway fare. This would imply that, as in the case of water navigation, there were no direct cost savings in railway livestock transport. However, this estimation ignores the loss of weight of livestock during their journey, which was much lower if the travel was made by railway. This issue gained relevance in the early $20^{\text {th }}$ century, when meat processing plants replaced salting houses as the main destination for a large share of the livestock transported and the unit value of cattle increased substantially as a result of crossbreeding (Martínez Díaz, 1987, p. 56; Rodríguez Carrasco, p. 144; Barrán and Nahum, 1973, pp. 442-3). ${ }^{11}$

Here I assume that livestock lost on average 15 percent of its weight and market value in a droving journey, and just 5 percent on an average railway journey. These are very tentative percentages based on some scattered evidence for cattle transport coming from Uruguay and other countries. ${ }^{12}$ If I use the price of cattle and sheep meat in the Montevideo wholesale markets in 1913 to value the differential loss associated with droving, and apply the result to the weight of animals moved by the railways in 191213 , the resulting cost difference would amount to 5.74 million pesos, and the total (direct plus indirect) cost of droving per ton-km would be 0.114 pesos, i.e. approximately seven times as high as the average railway rate. ${ }^{13}$

\footnotetext{
${ }^{10}$ Figure taken from the country's Statistical Yearbook.

11 By contrast, weight loss was not a serious problem in the case of livestock used for dried beef production during the $19^{\text {th }}$ century. This was clearly stated in the 1880 Central Uruguay Railway Yearly Report: "Our present limited wagon stock only admits of our bringing in lots of 150 to 200 head at a time, such small troops being for consumption in the city of Monte Video, while the larger troops of from 500 to 1,000 head for Saladero purposes are usually driven from up country all the way into town" (p. 7). The replacement of droving by the railways arrived quite rapidly between 1896 and 1905; whereas in the former year only 16 percent of the cattle transported to Montevideo was carried there by railways, that figure was 68 percent nine years later (Central Uruguay Railway, Report of the Directors to the Proprietors for the Half-Year Ended $31^{\text {th }}$ December, 1905, p. 23).

${ }^{12}$ The 5 percent ratio for railway transport comes from a study for Germany, which was reproduced in Revista de la Asociación Rural del Uruguay, XLII, 5 (1913), pp. 352-353, and the 15 percent ratio for droving has been deduced from average weight losses in $19^{\text {th }}$ century cattle droving in Britain, as reported by Colyer (1972) and Palmer (2002), p. 29. The 10 percentage point difference between both transport systems is consistent with a comparison reported in Revista de la Asociación Rural del Uruguay, XXXV, 4 (1906), p. 105, according to which a shipment of cattle transported to Montevideo by train was sold at a unit price 5.50 pesos higher than a similar shipment carried by droving.

${ }^{13}$ Cattle and sheep price and weight data in 1913 have been taken from the 1913-14 Uruguayan Statistical Yearbook.
} 
In addition to rate estimates, the calculation of the social savings of the Uruguayan railways requires making some assumptions on the percentages of railway freight that would have been transported by boats, carts and droving in the absence of railways. I consider, first, that all livestock railway transport (i.e. 18.8 of all railway freight), would have been moved by droving in the counterfactual economy, since domestic water transport of livestock was not developed in Uruguay during the period under study. ${ }^{14}$ Therefore, in the absence of the railways, I assume that 57.26 million ton-km would have been moved by droving, and would have been charged a unit (direct plus indirect) cost of 0.114 pesos per ton-km.

The remaining freight would have been distributed between ships and carts. Given the large difference between the rates of those two transport modes $(0.004 / 0.012$ vs. 0.056), assumptions on this issue have a considerable influence on the social saving estimation results. As has been indicated above, a significant share of the Uruguayan railway network ran very close to the Uruguay River and the La Plata estuary. In order to carry out the estimation, I have assumed that, in the counterfactual economy, boats would have transported all the freight (apart from livestock) moved among stations that were at a distance of $25 \mathrm{~km}$ or less from the Uruguay or La Plata riverbanks, including stations in the Montevideo area. ${ }^{15}$

Unfortunately, detailed information on traffic between stations is lacking for the year of reference. The Uruguayan Statistical Yearbook (1912-13) provides instead the total tons shipped from each station during the year, without indication of distance travelled or destination. Excluding livestock from the calculation, freight shipped from the stations that were closest to the rivers (apart from Montevideo) amounted to 20.2 percent of all tons moved by the railways. If this amount is increased by 20.2 percent of the freight sent from the Montevideo area to the rest of the country (under the assumption that traffic from Montevideo was distributed among different destinations according to the importance of each station in the total shipment of freight), this would

\footnotetext{
${ }^{14}$ See, for instance, Martínez Montero (1955), p. 403. I exclude pigs from livestock transport. They represented 1.5 percent of the total number of live animals moved by the railways and ca. 1.2 percent of livestock transport revenues. The second percentage is based on the average weights of different animals sold in Montevideo in 1913, which has been taken from the country's Statistical Yearbook.

${ }^{15}$ These would include, apart from the Montevideo stations, the whole line of the Ferrocarril Uruguayo del Este, the stations between Colonia Suiza and Puerto del Sauce/Colonia in the Central Uruguay Railway, those between Porvenir and Salto and between Bellaco and Fray Bentos in the Midland Uruguay Railway, and Salto and San Antonio in the North Western Railway. I do not consider here the traffic of the company of Puerto del Sauce due to lack of data.
} 
mean that 25.6 percent of all tons transported by the Uruguayan railways (livestock excluded) were shipped or received in stations where water transport was a feasible alternative. I therefore use this percentage as the share of non-livestock freight output that would be moved by boat in the counterfactual economy, and consider that all the rest would be transported by carts. ${ }^{16}$ The rate applied to cart transport is, as has been indicated, 0.0564 pesos per ton-km, and the counterfactual water transport rate is a weighted average of the two figures for long and short-distance travels (0.0042 and 0.0116 pesos per ton- $\mathrm{km}$ ), where weights are the estimated shares of traffic from and to North Western ports, and from and to ports in La Plata, respectively. ${ }^{17}$

Table 3 presents the results of the estimation of the social saving of railway freight transport in Uruguay in 1912-13, which accounted for a very small percentage of the country's GDP, compared with other Latin American countries, such as Mexico, Brazil or Argentina, where the ratio between the freight social savings and GDP was similar or higher than 20 percent. These results are therefore consistent with the hypothesis that the Uruguayan railways had a relatively low economic impact. ${ }^{18}$

\footnotetext{
${ }^{16}$ I assume therefore that transport flows ran mainly to and from Montevideo. I also assume that no live animals were shipped from the Montevideo area to the rest of the country.

${ }^{17}$ In order to estimate that average, I assume that traffic from the North West traveled a distance that was three times as large as that travelled by traffic from the South, on the basis of the relative average distance between those ports and Montevideo.

${ }^{18}$ Annex 1 presents a sensitivity analysis that reports the effects of the potential biases introduced in the social saving estimation by some of the assumptions made on the Uruguayan counterfactual economy, both for freight and passenger transport.
} 
Table 3. The social saving of Uruguayan railway freight transport (1912-13)

\begin{tabular}{|l|c|}
\hline 1. Railway economy & \\
\hline a) Railway freight (million ton-km) & 305.81 \\
b) Railway market fare (pesos per ton-km) & 0.016 \\
c) Railway freight revenues (million pesos) (a x b) & 4.742 \\
\hline 2. Counterfactual economy & \\
\hline c) Water transport freight (million ton-km) & 63.63 \\
d) Water transport rate (pesos per ton-km) & 0.0061 \\
e) Water transport cost (million pesos) (c x d) & 0.389 \\
\hline f) Carting transport freight (million ton-km) & 184.92 \\
g) Carting transport rate (pesos per ton-km) & 0.0564 \\
h) Carting transport cost (million pesos) $(\mathrm{f} \mathrm{x} \mathrm{g)}$ & 10.424 \\
\hline i) Droving output (million ton-km) & 57.26 \\
j) Droving unit cost (pesos per ton-km) & 0.114 \\
k) Droving total cost (million pesos) $(\mathrm{i} \mathrm{x}$ j) & 6.525 \\
\hline Social saving (million pesos) $(e+h+k-c)$ & 12.613 \\
\hline As a \% of GDP & 3.83 \\
\hline
\end{tabular}

Sources: See text and, for nominal GDP, see sources to Figure 2.

Those figures should be increased by the indirect costs of alternative transport means, which ranged from their lower safety and regularity to the need of holding higher stocks of circulating capital in order to overcome the longer duration of carting or navigation journeys. ${ }^{19}$ There were also some indirect differential costs of railway transport, such as the need for trans-shipping and the fact that carting transport had a very low opportunity cost in areas with high seasonality of agrarian work. ${ }^{20}$ However, as in estimates for other countries (Coatsworth, 1981; Summerhill, 2003), here these aspects have been kept apart due to the difficulty of their estimation.

\subsection{Passenger social savings}

In 1912-13 the passenger output of the Uruguayan railways amounted to 115.39 million passenger-km, which were charged an average rate of 0.018 pesos. The

\footnotetext{
${ }^{19}$ Uruguayan railway managers were well aware of the importance of these indirect benefits; for instance, the 1876 Yearly Report of the Central Uruguay Railway mentioned the advantage of holding lower capital stock, which was enjoyed by those merchants that used the railways (p. 12). See also "Necesidad del ferrocarril", Revista de la Asociación Rural del Uruguay, XXIII, 8 (1894), pp. 203-204, which stresses the importance of the higher uncertainty involved in road transport.

${ }^{20}$ On the problem of the presence of idle resources for the estimation of social savings see, for instance, Toniolo (1983); for Uruguay, see also Nahum and Barrán (1971), p. 623. This issue was also considered at the time; the 1876 Yearly Report of the Central Uruguay Railway, for instance, indicated that many farmers (especially those closer to Montevideo) had their own carts and bullocks and could devote some of their idle time to transport activities (Central Uruguay Railway, Report and Accounts for the Year 1877, p. 4; see also García Acevedo, 1892, p. 4).
} 
alternative transport means available to those passengers were river navigation, stagecoach transport, and mounted travel or walking. Railways provided travellers with substantial time savings compared with all those modes. The speed of Uruguayan passenger railways was around $34.4 \mathrm{~km} \mathrm{p} / \mathrm{h}$ in 1913, whereas river navigation and stagecoach speed might be estimated as 12 and $6.5 \mathrm{~km} \mathrm{p} / \mathrm{h}$, respectively. As for the average speed of foot travel, it might be assumed to be around $3 \mathrm{~km} \mathrm{p} / \mathrm{h} .{ }^{21}$ By contrast, rate savings were only relevant in comparison with stagecoach transport. Although information on passenger water transport rates is not abundant, they might be estimated as ca. 0.0048 pesos per passenger-km, on the basis of the available data on prices of the travel from Montevideo to Buenos Aires, i.e. less than one third of the railway average fare. $^{22}$ The fare of stagecoach transport would have been instead around 0.0614 pesos per passenger-km, ${ }^{23}$ or more than three times the railway rate.

When analysing the social savings of railway passenger transport in Mexico or Brazil, both Coatsworth (1981) and Summerhill (2003) make a clear-cut difference between first and second class transport, under the assumption that those two services were used by different social classes with different transport demand functions. First class passengers would have been among the wealthiest classes of society and, for them, the alternative for the railways would have been the stagecoach. By contrast, second class passenger would have resorted to mounted transport or walking in the absence of the railroads, because stagecoach rates would have been prohibitive for them. However, it is not clear that such a procedure is adequate for Uruguay, for two reasons. First, in Uruguay, water transport would have been a cheap alternative for second class passenger on many transport routes. But, second and more important, the difference between first and second class fares in Uruguay and, subsequently, between the users of those two classes, was too small as to justify a separate treatment. More concretely, in Uruguay the second class average fare was 81 percent of the first class one, whereas in Argentina it was 67 percent, in Brazil 57 percent, and in Chile and Mexico 38 percent

\footnotetext{
${ }^{21}$ Railway speed calculated on the basis of the timetable of a sample of 59 passenger trains of different routes, taken from Ferrocarril Central del Uruguay (1913). Passenger water transport speed was around $12 \mathrm{~km} \mathrm{p} / \mathrm{h}$ in the travel between Buenos Aires and Rosario after the adoption of steam, according to Zalduendo (1977), p. 53. This speed is consistent with Zaefferer de Goeneche (1987), p. 176. Stagecoach speed is calculated from information for several Uruguayan routes in Nahum and Barrán (1971), p. 624; I have based the estimation on the speed of the shortest trips reported, because the average distance of haul in passenger railway transport was just $60 \mathrm{~km}$ in 192-13. Walking speed is taken from Summerhill (2005), p. 85.

${ }^{22}$ Information in Zaefferer de Goeneche (1987), p. 202. I correct the rate to take into account the difference in travel distance between the Uruguayan ports and Montevideo by river and by train.

${ }^{23}$ Estimated from Nahum and Barrán (1971), p. 624.
} 
(see Herranz-Loncán, 2011). As a consequence of the similarity of the rates of both classes, and unlike what was usual in most railway systems, in Uruguay passenger transport output was lower in the second than in the first class. In that context, and due to the absence of a cheap railway passenger service, the total number of passenger transported was much lower in Uruguay than in other countries with a comparable level of income per capita, such as Chile or Argentina. ${ }^{24}$

Therefore, I assume here that there were no significant differences in Uruguay between the transport demand of the users of the first and second class railway services. Table 6 provides an estimate of the social savings of passenger transport, under the assumption that, in the absence of railways, all passengers would have travelled by either stagecoach or ship to their destination. The distribution of passengers among those two transport modes in the counterfactual economy is estimated in the same way as in the case of freight. ${ }^{25}$ Table 6 also includes an estimation of the time savings provided by the railways, under the assumption that railway passengers were among the wealthiest groups of society, and their working time was twice as valuable as that of skilled industrial workers. ${ }^{26}$ As in the case of freight, other indirect savings are excluded, such as those associated with the higher safety, comfort, regularity and predictability of the railways, or the increasing travel costs associated with meals during stagecoach travels (see e.g. García Acevedo, 1892, pp. 31-33).

\footnotetext{
${ }^{24}$ Whereas in Argentina and Chile the passengers transported by the railways in 1912/1913 amounted to 11 and 5 times the total population of the country, respectively, in Uruguay that ratio was 1.5. Differences were less marked with Brazil or Mexico, where that ratio was 2.2 and 1.2 respectively. However, income per capita in those two countries was significantly lower than in Uruguay.

${ }^{25}$ More precisely, I measure the percentage of total passengers that took the train in stations close to the riverbanks, except for Montevideo, and consider that twice that percentage (to account for return journeys) of the total passengers would have used ships in the counterfactual economy. The resulting share is 17 percent.

${ }^{26}$ Wage data for skilled workers in Montevideo in 1913 have been kindly provided by Luis Bértola. I assume a working day of 8.5 hours and consider, as in Coatsworth (1981) or Summerhill (2003) that only about half the time savings were savings in working time and must therefore be included in the estimation of the additional consumer surplus.
} 
Table 4. The social savings of railway passenger transport in Uruguay (1912-13).

\begin{tabular}{|c|c|}
\hline 1. Railway economy & \\
\hline a) Railway passenger transport (million passenger-km) & 115.39 \\
\hline b) Railway rate in pesos per passenger-km & 0.018 \\
\hline c) Railway passenger revenues (million pesos) ( $\mathrm{a} \times \mathrm{b}$ ) & 2.034 \\
\hline d) Unit value of working travel time in pesos per hour & 0.409 \\
\hline e) Working travel time by railway (million hours) (50 percent of a at $34.4 \mathrm{~km} \mathrm{p} / \mathrm{h}$ ) & 1.677 \\
\hline f) Value of the working travel time by railway (million pesos) ( $\mathrm{d} x \mathrm{e})$ & 0.686 \\
\hline 2. Counterfactual economy & \\
\hline g) Counterfactual water passenger transport (million passenger-km) & 19.11 \\
\hline h) Counterfactual water transport rate in pesos per passenger-km & 0.0048 \\
\hline i) Counterfactual water passenger transport cost (million pesos) ( $\mathrm{g} \mathrm{x} \mathrm{h}$ ) & 0.0922 \\
\hline j) Working travel time by water transport (million hours) (50 percent of $\mathrm{g}$ at $12 \mathrm{~km} \mathrm{p} / \mathrm{h}$ ) & 0.0038 \\
\hline k) Value of the working travel time by water transport (million pesos) $(\mathrm{d} x \mathrm{j})$ & 0.0016 \\
\hline 1) Counterfactual road passenger transport (million passenger-km) & 96.27 \\
\hline m) Counterfactual road transport rate in pesos per passenger-km & 0.0614 \\
\hline n) Counterfactual road passenger transport cost (million pesos) ( $1 \times \mathrm{m})$ & 5.915 \\
\hline o) Working travel time by road transport (million hours) ( 50 percent of 1 at $6.5 \mathrm{~km} \mathrm{p} / \mathrm{h}$ ) & 7.406 \\
\hline p) Value of the working travel time by road transport (million pesos) ( $\mathrm{d}$ x o) & 3.029 \\
\hline q) Savings on transport costs (million pesos) $(\mathrm{i}+\mathrm{n}-\mathrm{c})$ & 3.973 \\
\hline r) Savings on travel time (million pesos) $(k+p-f)$ & 2.345 \\
\hline s) Total savings (million pesos) $(q+r)$ & 6.318 \\
\hline w) As a percentage of GDP & 1.92 \\
\hline
\end{tabular}

Sources: see text and, for nominal GDP, see sources to Figure 2.

As in other Latin American countries, in Uruguay passenger transport savings appear to have been rather small. However, in contrast to Mexico, Brazil and Argentina, they had a sizeable magnitude relative to the social savings of freight transport, due to the low level of the latter.

\subsection{Correction for the price elasticity of demand.}

In order to obtain figures of additional consumer surplus, the social saving estimates reported in Tables 3 and 4 must be corrected to account for the elasticity of transport demand. I have estimated the following transport demand function for freight and passenger transport in the Central Uruguay Railway Company network which, as has been indicated, represented 61 percent of the country's mileage of track, between 1892 and 1913:

$$
\ln Q=\alpha+\beta_{1} \ln P+\beta_{2} \ln G D P+\beta_{3} \ln N+\beta_{4} \text { time }
$$


where $Q$ is railway freight/passenger transport, $P$ is the average market price of railway transport (expressed in constant pesos of 1913) and $N$ is the Central Company mileage in operation. The series included in the transport demand function have been subjected to the ADF unit root test in order to know their level of integration. The results of the test are shown in Table 4, and all series appear to be integrated of order one. The number of lags has been determined through the Schwartz criterion, and the test includes a trend and/or a constant when these are significant.

Table 5. Transport demand function. Unit root tests.

$\left(\mathrm{H}_{0}\right.$ : presence of a unit root)

\begin{tabular}{|l|c|c|c|c|}
\hline Variable & $\mathrm{n}^{\mathbf{0}}$ of lags & trend/constant & $\mathrm{DW}$ & ADF t-stat \\
\hline $\ln \mathrm{Q}_{\text {freight }}$ & 2 & $\mathrm{t}, \mathrm{c}$ & 2.04 & -2.48 \\
\hline $\ln \mathrm{Q}_{\text {pass. }}$ & 0 & $\mathrm{t}, \mathrm{c}$ & 1.98 & -2.91 \\
\hline $\ln \mathrm{P}_{\text {freight }}$ & 2 & none & 1.91 & -1.19 \\
\hline $\ln \mathrm{P}_{\text {pass. }}$ & 0 & $\mathrm{t}, \mathrm{c}$ & 1.71 & -2.24 \\
\hline $\ln \mathrm{GDP}$ & 0 & $\mathrm{t}, \mathrm{c}$ & 1.91 & -2.30 \\
\hline $\ln \mathrm{N}$ & 0 & none & 1.83 & 1.30 \\
\hline
\end{tabular}

Sources: own elaboration on the basis of information on output, rates and mileage of the Central Uruguay Railway, taken from the company's yearly reports, and GDP, from Bértola (1998). Railway rates have been expressed in pesos of 1913 using the deflator provided by Bértola (1998).

The results of the OLS estimation of function (2) for both freight and passenger transport are displayed in Table 5. The estimation output may be considered as the error correction vector of a cointegration model, since the residuals of the equation appear to be stationary. As might be expected, the estimate of price elasticity is significantly smaller in the case of freight (-0.77) than in the case of passenger transport (-1.06), and both are in line with figures for other countries.

Table 6. Uruguayan railway transport demand function (1891-1913)

\begin{tabular}{||l|c|c|}
\hline & Freight & Passengers \\
\hline$N$ & 22 & 22 \\
\hline$A d j R^{2}$ & 0.97 & 0.99 \\
\hline$\alpha$ & -42.31 & 1.31 \\
& $(33.27)$ & $(19.06)$ \\
\hline$\beta_{1}$ & $-0.77^{*}$ & $-1.06^{* *}$ \\
& $(0.27)$ & $(0.17)$ \\
\hline$\beta_{2}$ & $0.66^{*}$ & $0.83^{* *}$ \\
& $(0.28)$ & $(0.17)$ \\
\hline$\beta_{3}$ & 0.25 & $0.30^{* *}$ \\
& $(0.12)$ & $(0.07)$ \\
\hline$\beta_{4}$ & 0.02 & -0.0003 \\
& $(0.02)$ & $(0.011)$ \\
\hline ADF (residuals) & $-4.32^{* *}$ & $-3.67^{* *}$ \\
\hline
\end{tabular}

* significant at the 5 percent level; ** significant at the 1 percent level; standard errors in brackets Sources: see Table 5. 
According to these estimates, the additional consumer surplus provided by railway freight transport in Uruguay was 7.179 million pesos in 1912-13, i.e. 57 percent of the social saving estimate in Table 3 , and just 2.18 percent of the country's GDP. In the case of passengers, the additional consumer surplus was 3.151 million pesos, i.e. 60 percent of the social saving estimate in Table 4 and 0.96 percent of GDP. The sum of both amounts is 10.330 million pesos, or 3.1 percent of GDP, which is very small compared with the available estimates for other countries (9 to 14 percent of GDP in the case of Brazil, Mexico and Argentina; see Herranz-Loncán, 2011). The potential reasons for this low level are explored in Section 4.

\section{Why was the impact of the Uruguayan railways so low?}

A comparison with Argentina, a neighbouring country with a relatively similar economic evolution during the period under study and a comparable level of income per capita, may help to explain why the resource saving impact of the Uruguayan railways was so low. The social savings of the Argentinean railways, under the assumption of inelastic demand, can be estimated as 19.9 percent of GDP in the case of freight and 1.7 percent in the case of passengers (Herranz-Loncán, 2011). Passenger transport savings were very similar among both countries and, as in the case of Brazil and Mexico, they accounted for a rather tiny share of GDP. By contrast, freight social savings in Argentina were more than 5 times as high as in Uruguay, in relative terms. Apparently, resource savings in freight railway transport had a huge influence on the growth of the Argentinean economy, but rather discrete effects on the economic evolution of Uruguay.

The reasons for the different level of the economic benefits of railway freight transport in the two countries may be better understood if the ratio between the (uncorrected) social savings and GDP is decomposed as:

$$
\begin{aligned}
& S S / G D P=\left(P_{A L T}-P_{R W}\right) \times Q_{R W} / G D P= \\
& =\left[\left(P_{R W} \times Q_{R W}\right) / G D P\right] \times\left[\left(P_{A L T} / P_{R W}\right)-1\right]
\end{aligned}
$$

The first term is the ratio between railway freight revenues and GDP, and depends on both the amount of freight moved and the level of railway rates. The second term, in turn, depends on the distance between railway and alternative transport rates. Table 7 provides the level of those two terms in Argentina and Uruguay in 1912-13, as 
well as the average rate of railways and alternative transport means in both countries, expressed in a common currency (pounds sterling).

Table 7. The components of freight social savings in Argentina and Uruguay in 1912-13

\begin{tabular}{|l|c|c|c|c|}
\hline & $\begin{array}{c}\left(\mathrm{P}_{\mathrm{RW}} \times \mathrm{Q}_{\mathrm{RW}}\right) / \mathrm{GDP} \\
(\%)\end{array}$ & $\left(\mathrm{P}_{\mathrm{ALT}} / \mathrm{P}_{\mathrm{RW}}\right)-1$ & $\begin{array}{c}\mathrm{P}_{\mathrm{ALT}} \\
\text { (pounds per ton-km) }\end{array}$ & $\begin{array}{c}\mathrm{P}_{\mathrm{RW}} \\
\text { (pounds per ton-km) }\end{array}$ \\
\hline Argentina & 3.63 & 5.48 & 0.0130 & 0.0020 \\
\hline Uruguay & 1.44 & 2.65 & 0.0121 & 0.0033 \\
\hline
\end{tabular}

Sources: For Argentina, Herranz-Loncán (2011); for Uruguay, see text.

According to the table, Argentina enjoyed a clear advantage over Uruguay both in the size of the railway sector and in the difference between railway rates and the prices of alternative transport means. The latter, in turn, was affected both by the lower level of alternative transport prices and by the higher level of railway rates in Uruguay. Differences among alternative transport prices in those two countries are, however, hardly significant. Actually, almost 95 percent of the difference between the countries' social saving estimates can be explained by the fact that the railway sector was smaller and the railway rates higher in Uruguay. And, to a large extent, both factors might be reduced to a single one, since the most plausible reason for the high level of the Uruguayan rates was the low amount of freight transported by rail, which prevented from achieving scale economies in the sector. This is illustrated by Table 8 , which provides the estimation results of a simplified cost function of the Uruguayan and Argentinean railway companies by 1912-13. As the coefficients of both freight and passenger transport indicate, average variable cost per ton-km or passenger-km tended to decrease with output growth. 
Table 8. Variable cost function of the railway companies in Argentina and Uruguay (1912-13)

\begin{tabular}{|l|c|}
\hline Constant & $\begin{array}{c}-6.757^{* *} \\
(0.486)\end{array}$ \\
\hline log ton-km & $\begin{array}{c}0.303^{* *} \\
(0.099)\end{array}$ \\
\hline log passenger-km & $\begin{array}{c}0.241^{* *} \\
(0.067)\end{array}$ \\
\hline log mileage & $\begin{array}{c}0.476^{* *} \\
(0.118)\end{array}$ \\
\hline dummy Uruguay & 0.162 \\
& $(0.103)$ \\
\hline $\mathrm{n}$ & 22 \\
\hline Adj. $\mathrm{R}^{2}$ & 0.99 \\
\hline
\end{tabular}

Notes: The dependent variable is the log of the yearly operating costs, expressed in a common currency (pounds sterling).

** Significant at the 1 percent level; standard errors in brackets.

Sources: for Uruguay, the country's statistical yearbook for 1912-13; for Argentina, Estadística de los Ferrocarriles en Explotación (1913).

Note: The Argentinean Ferrocarril Transandino (a clear outlier) has been excluded from the estimation.

On the basis of that estimation, Figure 4 presents the adjusted relationship between average variable cost per ton-km and the size of freight output, keeping constant passenger output and network mileage. The figure clearly shows that the Uruguayan railway companies were situated in the most unfavourable section of the cost function. The problem, besides, was not associated to the fragmentation of the network in different companies but to the scale of the sector in each country, since the whole Uruguayan railway freight output (306 million ton-km) was just 15 percent of the output of the largest Argentinean company (the Ferrocarril Central Argentino). 


\section{Figure 4. Fitted relationship between freight output and average variable cost in the Argentinean and Uruguayan railway companies in 1912-13}

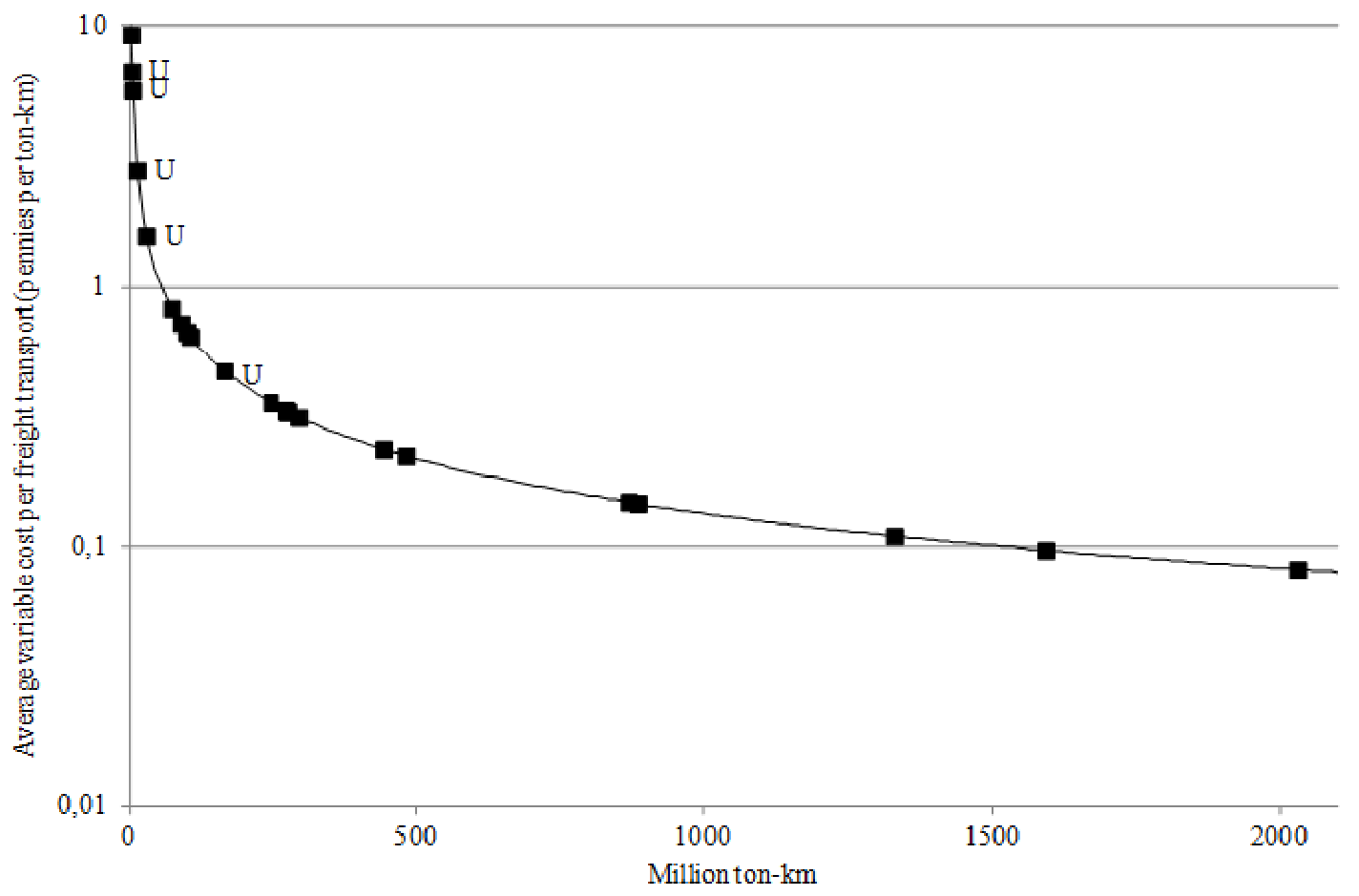

Sources and notes: See Table 8. The graph depicts the relationship between average variable cost per ton$\mathrm{km}$ and freight output that results from the cost function estimation in Table 8, after keeping constant all other variables at their average level. The Uruguayan companies are identified by an U.

Under these circumstances, the Uruguayan companies necessarily had to make up for the negative cost effects of low output by increasing rates. In other words, despite contemporaries demanding state regulation and fiercely criticising the high prices charged by the British-owned railways, ${ }^{27}$ there might actually have been relatively little margin for convergence of the Uruguayan railway rates with the Argentinean ones. This may be seen in Figure 5, which shows the relationship between freight and the unit rates applied by each company in Argentina and Uruguay by 1912-13.

\footnotetext{
${ }^{27}$ Criticisms to the high level of the Uruguayan railway rates are ubiquitous, both in the contemporary literature and in the historiography; see, for instance, García Acevedo (1892), pp. 207-11; Vázquez (1931); Acevedo (1934), pp. 50, 303 and 421; Baracchini (1978), p. 85; Barrán and Nahum (1967), p. 292; and (1973), pp. 446-449; Nahum and Barrán (1971), pp. 589-598; Martínez Díaz (1987), p. 75; Winn (2010), pp. 142 and 242. According to Nahum and Barrán (1971), Uruguayan railway rates were so high because they were adapted to both the characteristics of (transnational) transit trade and the features of livestock transport (seasonality and high value/volume ratio), and were not reduced when the former failed. Unlike the idea that is suggested in this paper, they affirm that those rates could have been decreased without loss for the companies, given the high level of net returns and the widespread presence of fraud in the companies' accounts (p. 595).
} 
Figure 5. Freight and rates in the Uruguayan and Argentinean railway companies in 1912-13

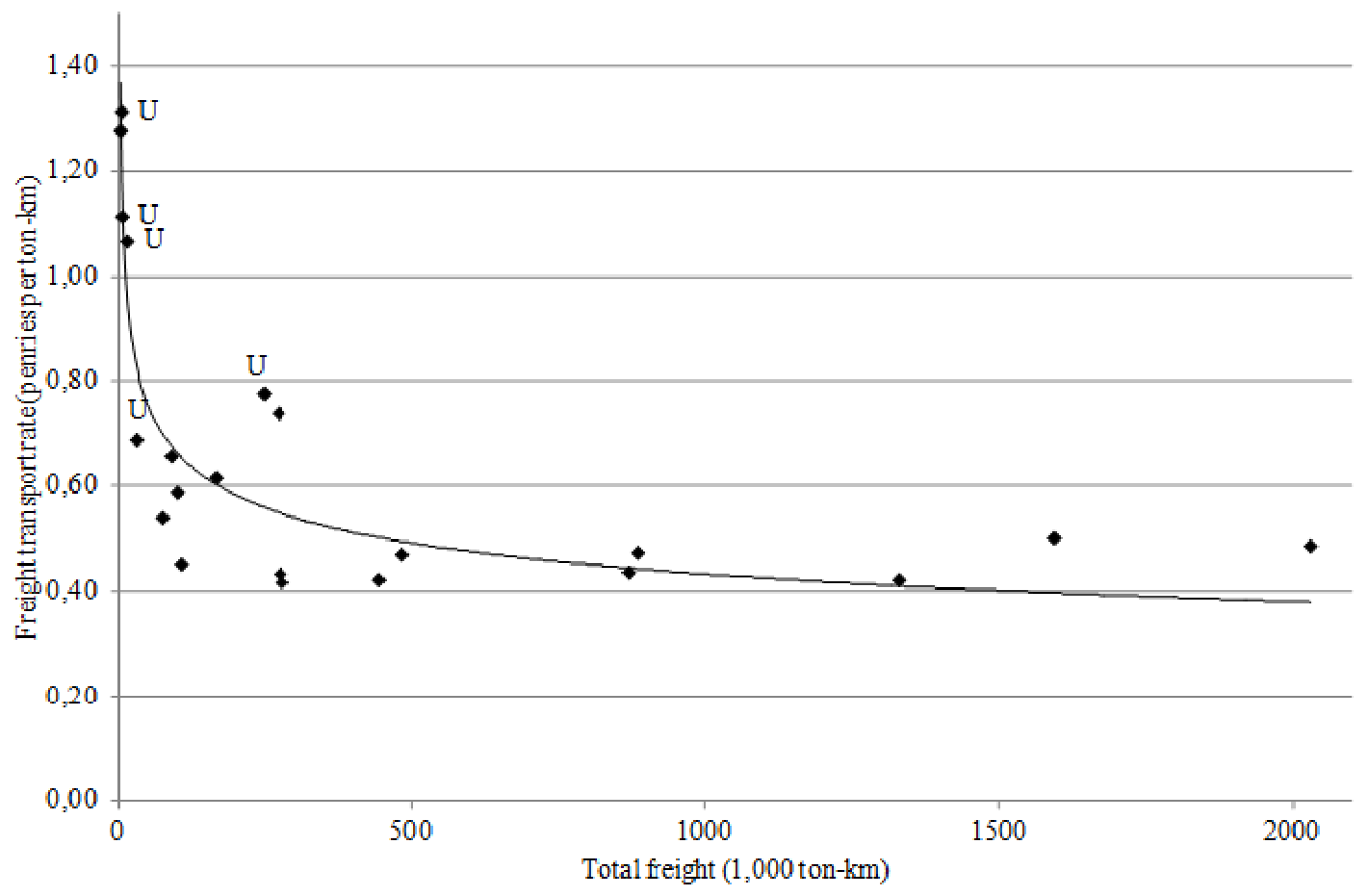

Sources and notes: See Table 8. The Uruguayan companies are identified by an U.

The application of high rates and an inelastic transport demand $(\varepsilon<1)$ explains that the average operating ratio of the Uruguayan companies was not worse than that of the companies of the neighbouring country. By 1912-13, the working expenses of the Uruguayan railway companies represented 57 percent of their gross revenues, a ratio that compared rather well with the equivalent Argentinean figure (62 percent in 1913). In addition, despite net revenues per $\mathrm{km}$ of line being significantly lower in Uruguay than in Argentina (245 vs. 317 pounds), economies in capital costs allowed the Uruguayan companies to get similar returns on capital as the Argentinean ones. More concretely, net revenues accounted for 4.04 percent of the total capital account of railways in Uruguay in 1912-13, compared to 3.97 percent in Argentina in 1913; and the average dividend distributed to ordinary shares by the Central Uruguay Railway between 1878 and 1914 was around 5 percent, if the worse years of the 1890 crisis are excluded (see Martínez Díaz, 1987: 80, and Barrán and Nahum, 1978: 145). ${ }^{28}$ However,

28 The reported capital costs of the Uruguayan railways were 6,007 pounds per km, vs. 8,133 in Argentina. The Uruguayan figure was similar to that of those European countries with lower railway construction costs, such as Finland, Norway, Sweden or Bulgaria; see Herranz-Loncán (2008). Actually, according to Barrán and Nahum (1978), p. 149, real construction costs were much lower than reported ones. 
this was only possible at the expense of cheap construction, shortage of rolling stock and a rather expensive and low quality transport service. ${ }^{29}$

Therefore, the main explanatory factor for the low level of the resource saving effects of the railways was probably the small amount of freight transported by the railway system, which affected the social savings both directly and through its impact on the level of railway rates. ${ }^{30}$ If railway freight is expressed in relation to the country's population, by 1913 railways were moving 263 ton-km per capita in Uruguay, whereas in Argentina they were transporting 1,201 ton-km per inhabitant, i.e. more than 4.5 times the Uruguayan figure. But, why was railway freight so low in Uruguay compared with Argentina? Here I suggest three complementary explanations: the geographic distribution of population and activity in each country, the sectoral structure of GDP and the scale of each economy.

Firstly, the distribution of population over the Uruguayan territory was clearly detrimental for railway transport. According to the 1908 Population Census, 30 percent of the country's inhabitants lived in the capital city, against just 14 percent in the case of Argentina. This crucially reduced the potential utility of the railways as suppliers of the Uruguayan population's general consumption needs. But, most importantly, 67 percent of Uruguayans lived in departments with a port or with easy access to river navigation. By contrast, this only happened with 28 percent of the Argentinean population, or 35 percent if the departments bordering the coastal ones are included in the calculation. ${ }^{31}$ Due to this difference, the Uruguayan economy depended much more heavily on water transport than its neighbour. By 1870, the rivers carried a very large proportion of the

\footnotetext{
${ }^{29}$ See e.g. Barrán and Nahum (1978), pp. 150-158, or Winn (2010), p. 252. Cheapness of construction was reflected in the lack of bridges and tunnels, and the circuitousness of the routes, and made transport costly, slow and low quality; criticisms on the bad quality on railway transport services were constant at the time. On this issue see e.g. Martínez Díaz (1987), p. 75; Millot and Bertino (1996), p. 345; or Acevedo (1934), pp. 564-55.

${ }^{30}$ See a somehow similar interpretation in Barrán and Nahum (1973), p. 436. The high level of the railway rates had also an augmenting effect on the social savings through the increase in the value of railway output. However, that effect was compensated by the decreasing effect of the reduction in the difference between railway and alternative transport prices. This reinforces the idea that the really relevant factor to account for the low level of the social saving was the size of the railway sector.

${ }^{31}$ Data on the population of coastal areas have been taken, in the case of Uruguay, from the country's statistical yearbooks, and, in the case of Argentina, from Randle (1981). For Uruguay, I have included the population of Montevideo, Canelones, Colonia, Maldonado, Paysandú, Río Negro, Rocha, Salto, San José and Soriano. For Argentina, I have taken into account all coastal or river departments of the provinces of Misiones, Santa Fe, Corrientes, Entre Ríos, Buenos Aires, Río Negro and Chubut, as well as the whole population of Formosa and Chaco. The second percentage for Argentina reported in the text considers both the coastal and river departments and the neighbouring ones, and it includes 48 percent of the population of Misiones, 71 percent of Corrientes, 91 percent of Santa Fe, 100 percent of Entre Ríos, 43 percent of Buenos Aires, 26 percent of Río Negro and 71 percent of Chubut, as well as the federal capital.
} 
total freight transport of the country, and their prominence did not disappear with the construction of the railway network. ${ }^{32}$ For instance, whereas the Argentinean GDP was 7.7 times as large as the Uruguayan one by 1910, in the case of the total weight of loaded ships entered in ports for domestic trade purposes, the ratio between both countries was just around 4.4. ${ }^{33}$

Secondly, the relative specialisation of the Uruguayan economy in extensive livestock production was clearly harmful for the growth of railway traffic density, due to the large land area that was required to produce each unit of output and the absence of return traffic (Barrán and Nahum, 1978, p. 172). ${ }^{34}$ In addition, those areas of Uruguay that were farther away from the ports were relatively more specialised in livestock, whereas agricultural areas, such as those west from Montevideo, enjoyed relatively easy access to water transport. By 1908/1913, for instance, the departments without access to the Uruguay River or La Plata estuary contained 58 percent of the Republic's livestock, but only 27 percent of the hectares devoted to cereal production. ${ }^{35}$ The situation was very different in Argentina, where those areas served by the railways in the inner parts of the country rapidly shifted into agriculture, thereby generating considerable flows of freight towards the ports and the urban markets (Cortés Conde, 1979). Table 9 compares the composition of railway freight transport in both countries and shows that the activity of Uruguayan railways was highly concentrated on three kinds of goods: building materials of very low value per ton (especially stone and sand, which were mainly transported by the Uruguayo del Este railway), live animals, and the so-called "frutos del país" (mainly animal products, such as wool or hides). Those three items accounted for 58 percent of the total tons carried in 1912-13. By contrast, in Argentina the products of agriculture (especially wheat and corn) and also agro-industry (such as sugar, wine or salt), accounted for 42 percent of the freight moved by the Argentinean railways.

\footnotetext{
${ }^{32}$ According to Millot and Bertino (1996), p. 315, 40 percent of wool was transported to Montevideo by river in 1869 and, still in 1900,15 to 20 percent of wheat received in the city came also by water. Similarly, Martínez Montero (1955, p. 397) indicates that, before the railways, 70 percent of the meat entered in Montevideo from the rest of Uruguay and Southern Brazil to be exported arrived there by river. ${ }^{33}$ GDP comes from Maddison's database, and data on the weight of loaded boats for domestic trade in each country comes from the respective statistical yearbooks; in the case of Uruguay, I have taken the average of the data for 1909 and 1911.

${ }^{34}$ By 1912, livestock production accounted for 39 percent of Uruguayan GDP vs. 15 percent in Argentina; see Cortés Conde (1994) and Bértola (1998).

${ }^{35}$ Figures calculated on the basis of the 1908 Livestock Census and the 1913-14 Statistical Yearbook.
} 
Table 9. The composition of railway freight transport in Uruguay and Argentina in 1912-13 (\%).

\begin{tabular}{|l|c|c|}
\hline & Uruguay & Argentina \\
\hline $\begin{array}{l}\text { "Country products" (Frutos del país: } \\
\text { wool, hides, bran, bones and horns, } \\
\text { etc.) }\end{array}$ & 15.33 & 4.22 \\
\hline Cereals and other agricultural products & 11.21 & 32.93 \\
\hline Industrial products & 0 & 9.41 \\
\hline Building materials & 26.82 & 12.01 \\
\hline General merchandise & 19.74 & 18.24 \\
\hline Animals & 15.56 & 10.06 \\
\hline $\begin{array}{l}\text { Railway companies' goods and } \\
\text { materials }\end{array}$ & 7.26 & 10.82 \\
\hline Coal & 4.08 & 2.31 \\
\hline TOTAL & 100 & 100 \\
\hline
\end{tabular}

Sources: for Uruguay, the Statistical Yearbook of 1913-14; for Argentina, Estadística de los Ferrocarriles en Explotación (1913).

Finally, in Uruguay the railways had to face the problem of the small scale of the country. The Uruguayan railway network had a similar structure to the Argentinean one, as a series of lines departing from the capital city-port and spreading through the countryside. However, compared with Argentina, the potential maximum travel distances were much smaller. This affected railway output in two ways. On the one hand, journeys between production areas and the main port of the country were shorter, which directly translated into a lower amount of ton-km of railway freight. On the other hand, the share of freight transport that was short-distance, and in which carts or droving could still compete with the railways, was much higher in Uruguay than in Argentina. As a consequence, in Uruguay competition between carts and railways remained very intense at least until the end of the $19^{\text {th }}$ century, because the sum of railway rates and transhipping costs made road transport competitive on many routes. ${ }^{36}$ As a result of cart competition on short distances and the easy access to river navigation, the percentage of total freight transport carried by the Uruguayan railways was comparatively small (see e.g. Winn, 2010, p. 142).

This helps to explain the key role that international transit trade had in $19^{\text {th }}$ century Uruguayan railway planning, and the insistence that Montevideo should become

\footnotetext{
${ }^{36}$ This was one of the main worries of the managers of the Central Uruguay Railway, and was constantly reflected in their yearly reports. Already in the Report for 1875 (p. 13) and 1878 (p. 7), when a railway line longer than $200 \mathrm{~km}$ was already in operation, they complained about the absence of paths towards the stations, which forced carts to make considerable roundabouts to feed the railways and led many of them to go directly to Montevideo. This made their business to be "almost confined to passenger traffic" in those early years (see Central Uruguay Railway, Report of the Directors to the Shareholders with Report of the General Manager for the Half-year ended June, 1874, p. 4). By 1877, only freight traffic beyond Santa Lucía (59 km from Montevideo) was conveyed by the railways (see Central Uruguay Railway, Report and Accounts for the Year 1877, p. 4).
} 
the node of a large intermodal network which would cover a large portion of the La Plata region, including Southern Brazil and parts of Paraguay and Argentina. ${ }^{37}$ If the Uruguayan railway network had been able to absorb a significant share of the export production of Southern Brazil, the size of the territory served by the railway network would have been much larger. Transit trade would have had a positive effect on railway rates even if it was "just circulation and not trade" (i.e. just transport from the neighbouring countries to the port of Montevideo without any involvement of Uruguayan agents; see Millot and Bertino, 1996: 317), due to the subsequent increase in the network density of use. However, this traffic was never very important, because of the delay in the development of Uruguayan railways in relation to the Argentinean ones, the slowness of the construction of both Uruguayan and Brazilian lines to the frontier, and the resistance of the Brazilian government to a closer relationship between its southern areas and Uruguay. Finally, transit trade prospects completely disappeared as soon as the new port in Brazil's Rio Grande do Sul was finished in $1915{ }^{38}$ These factors confined the scope of the Uruguayan railways to the country's territory, which was too small to generate enough traffic to make railways a significant growth factor.

Obviously, if low freight caused high rates, these further discouraged output growth, and reduced the ability of the railways to compete with alternative transport modes, such as droving, water transport or even carts. As a result, the Uruguayan transport system was trapped in a vicious circle, in which railway rates were high because transport flows were small, but the growth of the latter was prevented, among other factors, by a structure of transport prices that substantially reduced the advantages of the railways. In addition, as was often stressed by contemporaries and historians, the negative effects of this problem were worse in the case of agricultural commodities, which had a lower value per unit of weight than livestock products. As a consequence, the high railway rates discouraged structural change in the country. ${ }^{39}$ All this conspired

\footnotetext{
${ }^{37}$ See, for instance, García Acevedo (1892), pp. 192-3; Nahum and Barrán (1971), pp. 543-548; Millot and Bertino (1996), p. 334; Rodríguez Carrasco (1998), p. 131; or Winn (2010), pp. 63-64. However, although transit trade was present in the global design of the railway system, there is no agreement in the historiography on the interest of the railway companies on this kind of trade, apart from the North Western of Uruguay Railway Company. Whereas Nahum and Barrán (1971) consider that it was their main objective, Martínez Díaz (1987) thinks that it was only of minor importance for the companies during most of the period under study.

${ }^{38}$ Millot and Bertino (1996), p. 342. See also Costa (1902), or Winn (2010), p. 141.

${ }^{39}$ See, for instance, García Acevedo (1892), p. 193; Nahum and Barrán (1971), pp. 591-592; or Barrán and Nahum (1978), pp. 138-140. According to these authors, the Uruguayan railway companies were rather indifferent to the consequences of their rate policy on the agricultural underdevelopment of the country, and the high level of their rates may be considered as the main reason for that sector lack of
} 
to transform the Uruguayan railways into a relative failure, compared with the huge dynamism that the new transport infrastructure induced in countries such as Argentina, Brazil and Mexico. In sum, during its export-led growth episode, Uruguay was particularly ill-adapted to benefit from one of the essential technologies that drove the first globalisation boom.

\section{Conclusions}

In some Latin American countries, such as Mexico, Brazil and Argentina, the cost advantage of railways over traditional forms of transport during the first period of globalisation resulted in very large resource savings in freight transport, which was one of the bases on which those economies grew and developed during that time. Uruguay was among those Latin American countries that built a relatively dense railway network. However, unlike other economies in the region, the resource savings provided by Uruguayan railways were relatively small. Freight transport stayed at low levels and the cost advantage of railway rates over other forms of transport was not as high as in other countries.

There are several potential explanations for the small size of the Uruguayan railway sector: cheap water transport was available on many routes, the specialisation of the country in livestock production did not generate much transport output per $\mathrm{km}^{2}$, and the small scale of the country increased the share of short distance journeys over total transport, thereby reducing the competitiveness of the railways over traditional forms of overland transport. In other words, the geography of the country did not provide an adequate context for achieving all the potential benefits of the new technology.

\footnotetext{
dynamism. However, railway rates were not the only factor behind the low development of Uruguayan agriculture; for instance, Winn (2010), pp. 157-158, highlights the role played by the structure of land ownership, the system of rural credit and the conservatism of landowners. In addition, the companies repeatedly claimed that their future prospects crucially depended on the colonisation of the country and the growth of agricultural output. For instance the Report of the General Manager for the Half-year Ended June $30^{\text {th }}, 1881$ of the Central Uruguay Railway points out that: "Undoubtedly, the safest and most permanent source of traffic for our railway would be agricultural produce, and every effort should be made to promote immigration and colonization. With a population of small farmers on either side of the line traffic would be much heavier and more steady than it is at present" (p. 9); see similar statements in the Report for the Half-year Ended June 30 ${ }^{\text {th }}, 1879$, p. 7; the Report for the year ended $31^{\text {st }}$ December, 1879, p. 11; the Report for the Half-Year Ended December 31st, 1884 p. 7; or the Report for the Year Ended June 30th, 1888, p. 9. According to Winn (2010), p. 157, all the four main railway companies promoted agricultural colonies during the period.
} 
Uruguayan railways did produce some positive effects. They helped to integrate the national market while also promoting the political and administrative unification of the country (see Millot and Bertino, 1996, p. 328, or Barrán and Nahum, 1967, p. 294). But their economic impact was much lower than in other countries of the region that experienced export-led growth. This, indeed, may have affected the growth prospects of the Uruguayan economy, and should be taken into account when explaining its relative poor performance during the period under study. To sum up, the Uruguayan case provides a clear-cut case in which geography limited the potential of railway technology to generate significant levels of economic growth.

\section{References}

\section{A) Primary sources}

Central Uruguay Railway (CUR), Yearly and half-yearly reports (1874-1913).

The Midland Uruguay Railway Company, Yearly reports (1890-1913).

The North Western of Uruguay Railway Company, Yearly reports (1878-1903).

Revista de la Asociación Rural del Uruguay. 1894. XXIII, 8, pp. 203-204. 1906. XXXV, 4, p. 105. 1913. XLII, 5, pp. 352--353.

Sociedad del Ferrocarril y Tranvía del Norte, Yearly reports (1892-1913). Uruguay Statistical Yearbooks (1884-1915).

\section{B) Secondary sources}

Acevedo, E. (1934), Anales históricos del Uruguay. Tomo V, Montevideo, Barreiro y Ramos, S.A.

Baracchini, H. (1978), Historia de las comunicaciones en el Uruguay, Montevideo, Universidad de la República.

Barrán, J. P. and Nahum, B. (1967), Historia rural del Uruguay moderno (1851-1885) [Tomo I], Montevideo, Ediciones de la Banda Oriental.

Barrán, J. P. and Nahum, B. (1973), Historia rural del Uruguay moderno. Tomo III. Recuperación y dependencia 1895-1904, Montevideo, Ediciones de la Banda Oriental.

Barrán, J. P. and Nahum, B. (1978), Historia rural del Uruguay moderno. Tomo VII. Agricultura, crédito y transporte bajo Batlle 1905-1914, Montevideo, Ediciones de la Banda Oriental.

Bertino, M. and Tajam, H. (1999), El PBI de Uruguay, 1900-1955, Montevideo, Universidad de la República, Instituto de Economía.

Bértola, L. (1998), El PBI de Uruguay 1870-1936 y otras estimaciones, Montevideo, Universidad de la República, Facultad de Ciencias Sociales.

Bértola, L. (2000), Ensayos de Historia Económica. Uruguay y la región en la economía mundial, 1870-1990, Montevideo, Trilce.

Coatsworth, J. H. (1981), Growth against Development: The Economic Impact of Railroads in Porfirian Mexico, DeKalb, Northern Illinois University Press. 
Colyer, R. (1972), "Welsh Cattle Drovers in the Nineteenth Century", National Library of Wales Journal, XVII, 4.

Cortés Conde, R. (1979), El progreso argentino, 1880-1914, Buenos Aires, Editorial Sudamericana.

Cortés Conde, R. (1994), "Estimaciones del producto bruto interno de Argentina 18751935", Universidad de San Andrés, WP 3.

Costa, Á. F. (1902), Puertos y ferrocarriles. La Coronilla, San Luis y la Laguna Merim. El ferrocarril ístmico y sus ramales. El porvenir económico de Río Grande del Sur. Una solución internacional (conferencia), Montevideo, Barreiro y Ramos.

Dobado, R. and Marrero, G. A. (2005), "Corn Market Integration in Porfirian Mexico", Journal of Economic History, 65, 1, pp. 103-128.

Ferrocarril Central del Uruguay (1913), Itinerario de servicio para el uso y gobierno de los empleados de la empresa exclusivamente. Desde el 15 de Diciembre de 1913 hasta nuevo aviso, Peñarol, Imprenta F.C.C.

García Acevedo, Carlos (1892), Estudio sobre ferrocarriles. Tesis presentada para optar al grado de Doctor en Jurisprudencia, Montevideo, Dornaleche y Reyes.

Herranz-Loncán, A. (2008), Infraestructuras y crecimiento económico en España, 1850-1935, Madrid, Fundación de los Ferrocarriles Españoles.

Herranz-Loncán, A. (2011), "The Contribution of Railways to Economic Growth in Latin America before 1914: a Growth Accounting Approach", paper presented at the EHES Conference, Dublin, 2-3 September 2011.

Kuntz Ficker, S. (1999), "Los ferrocarriles y la formación del espacio económico en México, 1880-1910", in Kuntz Ficker, S. and Connolly, P. (coord.), Ferrocarriles y Obras Públicas, México, Instituto Mora, pp. 105-137.

Maddison, A. (2001), The World Economy: A Millennial Perspective, Paris, OECD.

Martínez Díaz, N. (1987), Los ferrocarriles británicos en Uruguay. Desde sus orígenes hasta la crisis del 90, Montevideo, Ediciones del Nuevo Mundo, Cuadernos Uruguayos $n^{\circ} 4$.

Martínez Montero, H. (1955), El río Uruguay. Geografía, historia y geopolítica de sus aguas y sus islas, Montevideo, Revista Histórica.

Metzer, J. (1984), "Railroads and the Efficiency of Internal Markets: Some Conceptual and Practical Considerations", Economic Development and Cultural Change, 33, 1, pp. 61-70.

Millot, J. and Bertino, M. (1996), Historia Económica del Uruguay. Vol. II. 1860-1910, Montevideo, Fundación de Cultura Universitaria.

Mitchell, B.R. (2003a), International Historical Statistics. Europe 1750-1993, Basignstoke, Palgrave McMillan.

Mitchell, B.R. (2003b), International Historical Statistics: The Americas, 1750-2000, Basignstoke, Palgrave MacMillan.

Mourat, Ó. (1973), La crisis comercial en la cuenca del Plata (1880-1920), Montevideo, Ediciones de la Banda Oriental.

Nahum, B. and Barrán, J. P. (1971), Historia rural del Uruguay moderno. II. 1886-1894 (La crisis económica), Montevideo, Ediciones de la Banda Oriental.

O'Brien, P. (1977), The New Economic History of Railways, London, Croom Helm.

Palmer, M. (2002), Industry in the Landscape, 1700-1900, London, Routledge.

Randle, P. H. (1981), Atlas del desarrollo territorial de la Argentina, Buenos Aires, Oikos.

Rodríguez Carrasco, Á. (1998), "El ferrocarril en la Cuenca del Plata", in Sanz Fernández, J. (coord.), Historia de los ferrocarriles de Iberoamérica (18371995), Madrid, Ministerio de Fomento, pp. 121-167. 
Summerhill, W. (2000), "Profit and Productivity on Argentine Railroads, 1857-1913", Los Angeles, UCLA, Department of History, UCLA (mimeo).

Summerhill, W. (2003), Order Against Progress. Government, Foreign Investment, and Railroads in Brazil, 1854-1913, Stanford, Stanford University Press.

Summerhill, W. (2005), "Big Social Savings in a Small Laggard Economy: RailroadLed Growth in Brazil", Journal of Economic History, 65, 1, pp. 72-102.

Summerhill, William R. (2006), "The Development of Infrastructure", in BulmerThomas, Victor; Coatsworth, John and Cortés Conde, Roberto (eds.), The Cambridge Economic History of Latin America. Vol. 2: The Long Twentieth Century, Cambridge, Cambridge University Press, pp. 293-326.

Toniolo, G. (1983), "Railways and Economic Growth in Mediterranean Countries: Some Methodological Remarks", in O'Brien, Patrick (ed.), Railways and the Economic Growth of Western Europe, London, McMillan, pp. 227-236.

Vázquez, F. P. (1931), Carreteras y ferrocarriles del Estado, Montevideo, La Platense. Winn, Peter (2010), Inglaterra y la Tierra Purpúrea. Gran Bretaña y Uruguay en el siglo XIX. Tomo II. Boom, quiebre e imperio económico 1880-1903, Montevideo, Ediciones de la Banda Oriental.

Zaefferer de Goeneche, A. (1987), La navegación mercante en el Río de la Plata, Buenos Aires, Emecé.

Zalduendo, E. A. (1977), "Las economías regionales en la Argentina de mediados del siglo XIX”, Cuadernos de la Facultad de Ciencias Sociales y Económicas, 2, pp. 39-55.

\section{ANNEX 1}

\section{SENSITIVITY ANALYSIS OF THE SOCIAL SAVING ESTIMATES}

The social saving estimations that have been presented in Section 3 may be biased due to the potential mistakes involved in certain assumptions on the counterfactual economy. Here I consider the potential effects of mistakes in three different areas: i) prices of carting transport; ii) the share of railway transport that would be replaced by river navigation in the event of a closure of the railway network; and iii) the assumption that there were no significant differences in Uruguay between the transport demand of the users of first and second class railway services.

Regarding the first aspect, it might be argued that the carting rate that has been applied in the estimation is too low because most observations of carting transport prices come from sources aimed at criticising the high level of railway prices and, as a consequence, they might be downward biased. Here I consider the possibility that prices in the first six roads of Table 2 are downward biased and analyse the effect of using two different estimates of carting rates. On the one hand, I estimate a new rate of 0.067 pesos per ton-km, on the basis of the observations of the two last roads of Table 2 and 
the price reported by the Central Uruguay Railway in $1882 .{ }^{40}$ On the other hand, I apply the rate estimated by Summerhill (2000) for Argentina (equivalent to 0.0774 Uruguayan pesos per ton-km). The outcomes of those exercises are an increase in the (uncorrected) social saving of freight transport from 3.82 percent of GDP to 4.42 and 5.00 percent, respectively. ${ }^{41}$

Secondly, I assume that the share of the railway transport that might be replaced by river navigation in the event of a closure of the railway network was 50 (150) percent of the share assumed in Table 3. This change would produce an (uncorrected) freight social saving of 4.31 (3.34) percent of GDP, instead of 3.82. Finally, if I abandon the assumption that there were no social differences between first and second class passengers and apply instead an estimation strategy similar to that used by Coatsworth (1981) and Summerhill (2003) for Brazil and Mexico, the (uncorrected) social savings of passenger transport would decrease from 1.92 to 1.26 percent of GDP. ${ }^{42}$

These sensitivity analyses would indicate that biases associated to the assumptions introduced in the estimation might be not serious enough as to invalidate the general conclusion that the Uruguayan social savings were significantly lower than in other countries of the region. Actually, on the basis of these exercises, the maximum ratio between the (uncorrected) social saving and GDP would be 5.69 percent in the case of freight and 2.17 percent in the case of passengers. ${ }^{43}$ Correcting by the elasticity of demand, these estimates would become 2.79 and 1.02 respectively. It is true that these figures exclude a large share of the indirect cost savings provided by the railways. However, those benefits are also absent from other countries' estimates, and it is rather doubtful that they could affect the general impression of a railway system with a comparatively low impact in terms of resource savings.

\footnotetext{
${ }^{40}$ It could be argued, however, that the rates reported in the last two rows of Table 2 are affected by the opposite problem from the rest: they come from documents aimed at criticising the high level of road transport rates.

${ }^{41}$ These figures and the following are based on the assumption of a zero demand elasticity, as the estimates in Table 3 and 4.

42 This correction means that: i) the time savings of second class passenger are valued at half the price of those of the first class; ii) in the case of the second class, the alternative to the railways in overland transport was walking.

${ }^{43}$ This is the result of assuming: i) the maximum carting rate $(0.0774)$ for freight, and ii) the minimum share (50 percent of the original estimate) for water transport, both for freight and passengers.
} 